\title{
UPPER QUATERNARY SEA LEVEL FLUCTUATIONS AND STILLSTANDS ON THE CONTINENTAL SHELF OF SÃO PAULO STATE, BRAZIL: A SUMMARY
}

\author{
Valdenir Veronese Furtado
}

\begin{abstract}
Sea level fluctuations are mainly related to glacial and deglacial events. São Paulo (Brazil) continental shelf shows many features, like terraces and sedimentary scarps, associated to older periods of sea level stillstands and drowned valleys, related to regressive and transgressive events. Although these features show well defined spatial position obtained through bathymetric analysis; they lack isotopic dating, which prevents from obtaining more accurate space-temporal positions. However, correlations with similar depths along the Brazilian continental shelf and the dating of a feature in the area enabled us to elaborate an estimated sea level variation curve for São Paulo continental shelf and coastal areas, since the Last Glacial Maximum.
\end{abstract}

Keywords: sea level fluctuations, bottom topography, sedimentary features, São Paulo continental shelf.

RESUMO. As flutuações relativas do nível do mar, de caráter global, estão associadas a eventos climáticos de glaciação e degelo. Embora não tenham ocorrido glaciações no hemisfério sul, durante o Quaternário, exceto na Antártica, a plataforma continental de São Paulo apresenta feições morfológicas ligadas à última glaciação e ao período pós-glacial subsequente. Caracterizam-se por terraços e escarpas sedimentares, associados a períodos de estabilizações do nível do mar e paleocanais fluviais afogados, relativos ao Último Máximo Glacial e à posterior transgressão marinha. Essas feições, embora com posições espaciais bem definidas, através de análises batimétricas, apresentam lacunas de datação isotópica que não permitem o estabelecimento de posições espaço-temporais mais precisas. No entanto, correlações com profundidades similares ao longo da plataforma continental brasileira e datação de uma feição na área, permitiram a elaboração de uma curva tentativa de variação do nível do mar, desde o Último Máximo Glacial, para a plataforma continental de São Paulo e áreas costeiras.

Palavras-chave: flutuações relativas do nível do mar, topografia de fundo, feições sedimentares, plataforma continental de São Paulo. 


\section{INTRODUCTION}

Global sea level fluctuations are associated with glacial and deglacial events. The first eustatic curves prepared were, presumably, global, since climate action was considered to be the sole responsible for the phenomenon. Although Mörner (1976) considered glaciation and deglaciation as extremely important for the process, he also pointed out the relativity of the curves due to regional tectonic phenomena and geoid variation. Mörner (op. cit.) observations prevent, therefore, the indiscriminate use of a eustatic curve at different locations.

The effect of sea level fluctuations on the continental shelf during the Quaternary has been extensively studied since the early 60 s. The sub-aerial exposure of the shelf during marine regressions favors the action of the continental and coastal dynamics on the area. Channels are carved and terrigenous sediments are transported to the upper slope and, as the sea retreats, sequences of crests are formed on the exposed surface of the continental shelf. The equilibrium is displaced towards the coastal portion corresponding to the current shelf edge.

In the subsequent transgression, previously deposited continental sediments are redistributed in equilibrium with the new environmental conditions. The drowning of terrigenous sediment sources inhibited their transfer to the outer portions, thus restricting continental contribution to the coastal vicinity. Depositional sedimentary structures such as the old shoreface were totally or partially reworked, or even covered by transgressive sediments with expression only in sub-surface. Swift (1976) relates the presence of terraces on the continental shelf to a sea level stillstand occurred in the Holocene transgression. This author also considers that the presence of scarps is related to drowned shorelines, being relics of lower shoreface partially eroded by faster transgressions. Slower transgressions would not allow its relief expressions on the surface, while submerged valleys can present surface expression or in subsurface caped by sediments.

\section{Upper quaternary sea level fluctuations on the Brazilian continental shelf}

Based on these assumptions, several studies have been conducted on the Brazilian continental shelf associating surface topographic expressions to sea level stillstands.

Notwithstanding the comments by Mörner (1976), many studies due to the lack of more detailed information that would enable to elaborate a eustatic curve specifically for the Brazilian continental shelf, use the curve of Millimann \& Emery (1968) to correlate the sediment samples of the area. This curve dates the last regressive maximum between 16,000 and 14,000 years
$\mathrm{BP}$, reaching a depth of 130 meters. Other authors, such as Maclntyre et al. (1978) date the glacial maximum approximately 18,000 years BP, presenting data that corroborate the Curray curve (1965, apud Maclntyre et al., op. cit.). The last date has been currently adopted as the best to express the last regressive maximum. The achieved depth is about $-125 \mathrm{~m}$ according to the curve of Curray (op. cit.). This position, however, cannot be used indiscriminately to correlate different areas.

Most of the studies about the Brazilian continental shelf are located in the Southeastern and Southern regions, as well as some observations at the mouth of the Amazonas River and Abrolhos region.

Kowsmann \& Costa (1974) discuss sea level positions taking into account based on areas rich in coarse fraction terrigenous components. In the Southern region, the authors identified an area that extends from the shoreline to the 60-meter isobath and, considering the current lack of contribution from terrigenous, interpreted this outer boundary as formed by palimpsests sediments. They also identified a second area at -105 meters and a third one at -170 meters, and considered them as former sea level stillstands. The authors indicate terrigenous accumulation peaks at $-50,-90 / 110$ and -170 meters in the Northern region. However, there is no absolute dating of these levels.

Kowsmann et al. (1977) observed the occurrence of scarps at -60 and $-110 \mathrm{~m}$ on the continental shelf of Rio Grande do Sul, which were associated with stillstand periods between 16,000 and 7,000 years BP. They also observed records of filled channels on the São Paulo continental shelf.

Kowsmann \& Costa (1979) examined evidence of sea level fluctuations on the Brazilian continental shelf and determined six stillstand levels, as follows:

a) -130 meters, dated to 15,000 years $\mathrm{BP}$ by ${ }^{14} \mathrm{C}$ method and comparatively placed according to the Millimann \& Emery (1968) curve, consisting of carbonate sediments (bioclastic) and erosional terraces;

b) -110 meters, dated between 14,000 and 13,000 years $\mathrm{BP}$ by ${ }^{14} \mathrm{C}$ method, consisting of terrigenous sediments, shoreface cliffs and erosive terraces;

c) -90 and -75 meters, both dated between 12,000 and 11,000 years BP comparatively, according to the Milliman \& Emery (op. cit.) curve, consisting of erosive terraces;

d) -60 meters, dated to 11,000 years $\mathrm{BP}$ by ${ }^{14} \mathrm{C}$ method, consisting of terrigenous sediments, erosive terraces and Abrolhos paleolagoon (Vicalvi et al., 1975 apud Kowsmann \& Costa, 1979); 
e) -40 meters, comparatively dated to 9,000 years BP according to the Milliman \& Emery (op. cit.) curve, consisting of erosive terraces and scarps.

Corrêa (1979) and Corrêa et al. (1980, 1989), while analyzing bathymetric charts in detail, reported that the continental shelf that extends from Rio de Janeiro to Rio Grande do Sul display flattened features, which were associated to sea level stillstands during the transgressive process. These features are located from -20 to $-25 \mathrm{~m},-32$ to $-45 \mathrm{~m},-60$ to $-75 \mathrm{~m}$ and -80 to $-90 \mathrm{~m}$. Corrêa et al. (1980) proposed for the aforementioned levels the following ages, respectively: 7,500; 9,000 to 10,000; 11,000 and 11,500 years BP. The datings were calculated based on the Milliman \& Emery (op. cit.) curve.

Corrêa (1990) places the sea level on the continental shelf of Rio Grande do Sul at the following positions: $-120 /-130 \mathrm{~m}$, $-100 /-110 \mathrm{~m},-60 /-70 \mathrm{~m},-32 /-45 \mathrm{~m}$ and $-20 /-25 \mathrm{~m}$ dated to 17,$500 ; 16,000$ and 11,000 years $B P$, for the three deepest levels, respectively, and the interval between 11,000 and 6,500 years $B P$, for the two shallower levels.

Regarding the last regressive maximum, most studies about sea level fluctuations on the Brazilian continental shelf place it between 110 and $130 \mathrm{~m}$ below current sea level. These estimates were obtained from topographic evidence, occurrence of biodetritic levels, terrigenous components and, in some cases, dating following the ${ }^{14} \mathrm{C}$ method. These datings, however, are not conclusive.

Kowsmann \& Costa (1974), as previously indicated, discussed the possibility of two positions for this regressive maximum. The least probable, according to the authors themselves, places it at $-170 \mathrm{~m}$ with a continental shelf subsidence rate of $0.3 \mathrm{~cm} /$ year; while the second, places it at -110 , at a lower subsidence rate. Kowsmann et al. (1977) and Kowsmann \& Costa $(1978,1979)$ analyzed cores, records of $3.5 \mathrm{KHz}$, organism associations and ${ }^{14} \mathrm{C}$ datings and concluded that the regressive maximum can be placed at least $100 \mathrm{~m}$ below the current sea level, the most probable position when establishing correlations with the pre-existing eustatic curves being -130 meters. Corrêa (1990) inferred a position -120/-130 meters through topographic and textural analysis.

\section{Ocean bottom morphology and sea level fluctuations on São Paulo continental shelf}

Studies about ocean bottom morphology have been made since the early 70s as shown in the works of Martins et al. (1972) and Zembruscki et al. (1972). A more accurate geomorphological characterization was performed by Zembruscki (1979) who split the shelf into inner, middle and outer and identified the presence of gradients. For São Paulo northern shelf, this author defined a first slope that extends to the $60-\mathrm{m}$ isobath, changing to a narrower inner shelf. The middle shelf is replaced by a second slope, which extends from $80 \mathrm{~m}$ to $100 \mathrm{~m}$ deep, and from there on, starts the outer shelf. This author also identifies a series of shallow and narrow channels, approximately perpendicular to the general slope, and suggests that they consist of paleo drainage developed in the regressive maximum at 18,000 years $\mathrm{BP}$ and drowned during Holocene transgressive events.

The studies about ocean bottom topography have also sought to relate expressions of submerged relief to eventual sea level stillstand periods as in Kowsmann et al. (1977), Corrêa et al. (1989) and Corrêa et al. (1996). The latter work extends to the São Paulo shelf the interpretations made by Corrêa (1990).

Costa et al. (1988) while analyzing bathymetric charts in detail reported for the northern São Paulo shelf the presence of scarps at $-60,-110$ and $-130 \mathrm{~m}$.

The authors seek in these studies to correlate the submerged features to global curves and, as in the case of the study by Kowsmann et al. (1977), to a small number of datings.

Furtado et al. (1992) analyzed the Directory of Hydrography and Navigation (DNH) board charts for the São Paulo coast and defined five intervals that can be related to sea level stillstand periods. The first interval, between -15 and $-20 \mathrm{~m}$, could be associated with the current period. The second interval, between $-30 \mathrm{~m}$ and $-40 \mathrm{~m}$, could correspond according to the literature, to 9,000 years BP. The third interval, between $-60 \mathrm{~m}$ and $-70 \mathrm{~m}$ could also according to the literature correspond to 11,000 years BP. The fourth interval, between $-80 \mathrm{~m}$ and $100 \mathrm{~m}$, is correlated in the literature to ages between 11,000 and 12,000 years BP. The fifth interval at $-130 \mathrm{~m}$ correlates, according to the literature, to an age of $17.420 \pm 270$ years BP dated for Rio Grande do Sul. However, according to the authors these ages are not accurate since there is no reliable dating for the São Paulo shelf.

Several studies that seek to correlate the sedimentary morphological features of the São Paulo continental shelf to former sea level stillstands have used, as in Reinhardt et al. (1993), georeferenced information systems, seeking to highlight the presence of these features and checking the lateral extension. South of São Sebastião Island cliffs that extend westward between the 90 and 120 meter isobaths were observed. There is also a valley that extends from the southern entrance of the São Sebastião Canal towards the shelf breaking. This valley, identified by Zembruscki (1979), is associated to regressive periods and 


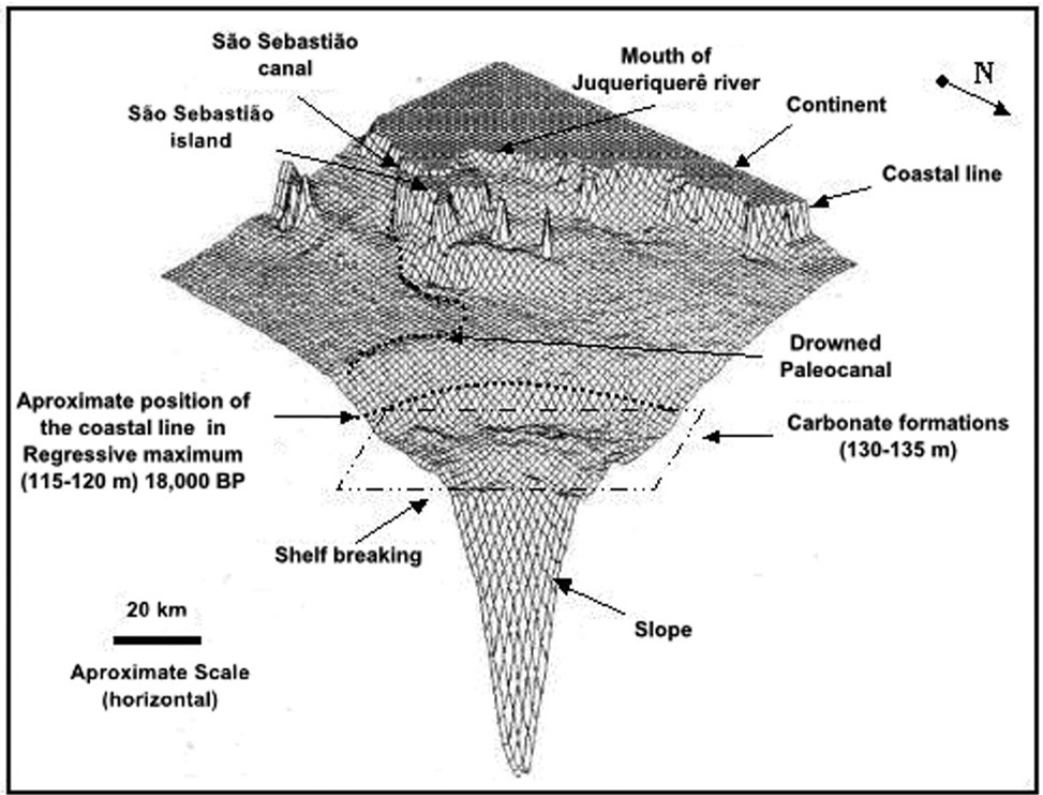

Figure 1 - Digital terrain model of the north central continental shelf of São Paulo. Based on Furtado et al. (1996).

consequent sub-aerial erosion. Furtado et al. (1996) used a digital terrain model (DTM) to detail the paleo-valley and considered it to be the main route to the sea ingression into coastal regions in the subsequent transgression. Currently, this submerged valley conditions the ingression of South Atlantic Central Water into coastal regions like the São Sebastião Canal (Fig. 1).

Furtado et al. (1993) based on the work of Reinhardt et al. (op. cit.), associate the topographic data to seismic records and sediments. The subsurface information allowed to identify subsurface valleys caped by transgresive sedimentss; escarpment areas where truncation of sedimentary layers are observed, similar to those occurring on beaches, due to on shore-off shore transportation; exposed rough surfaces, similar to the topography of beach sandstone; and, the presence of a high basement indicating a possible former barrier to the transgressive sea. These features indicate processes of sub-aerial erosion and possible former sea level stillstand.

This study also identified an irregular surface between the bathymetric interval of -130 and $-135 \mathrm{~m}$, with slopes up to 15 meters presenting on the surface carbonate levels higher than $70 \%$. This last area has been studied in more detail and Furtado et al. (1997), while analyzing sediment samples of this bathymetric interval, reported the occurrence of incrusted coralline algae and macro-foraminiferans, characteristic of a carbonate domain. The authors suggest through these indications a position for sea level stillstand at least $10 \mathrm{~m}$ above the shallower area $(-130 \mathrm{~m})$ and associate it to the last regressive maximum of approximately
18,000 years BP. It was possible from the existing data and ocean bottom topographic features to infer a sea level fluctuation curve from the last glacial maximum (Fig. 2). Although the data can support consistent hypotheses, they are not conclusive, but are goals to be researched in further projects that should be developed in the area.

\section{FINAL CONSIDERATIONS}

There is a lack of data to adequately analyze the quaternary evolution of the continental shelf in São Paulo and its submerged coastal region.

The level of information about shallow structures and paleolevel evidences, which permit to evaluate the process and its relation with sea level fluctuations, is still low.

There is practically no dating performed in the submerged area that enables to correlate sea paleolevels from a spatiotemporal view point, and still, many paleo-surfaces are inferred from the abrasion terrace which in addition to not being time correlated, may include errors regarding their spatial position (on the depth at which the surface was eroded).

There is need for further research either obtaining subsurface data that enable better identification of features correlated with sea level fluctuations or collecting materials amenable to dating, that allow a better spatiotemporal identification of eventual stillstand levels and the development of a curve that represents adequately the sea level fluctuations on the continental shelf of São Paulo. 


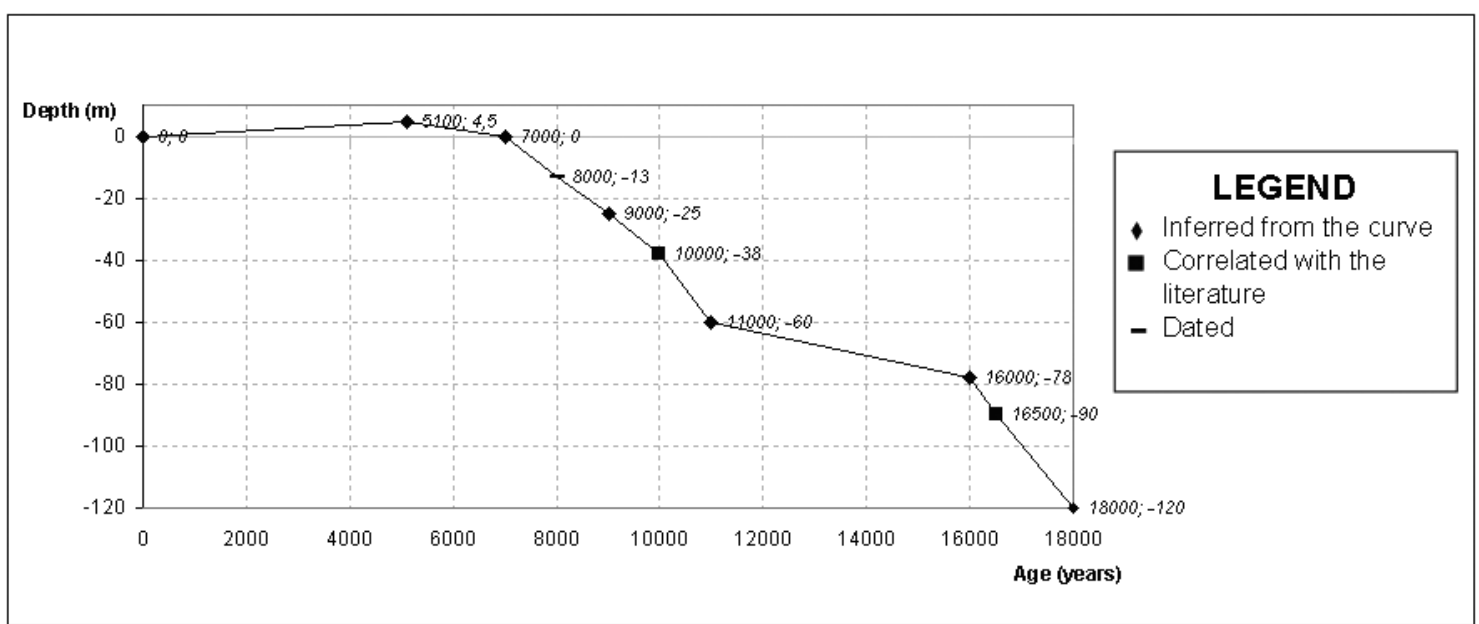

Figure 2 - Curve inferred to describe the sea level stillstands on the continental shelf of São Paulo, after the last Glacial Maximum. Based on Vicalvi et al. (1978); Corrêa (1996); Furtado et al. (1998) and Conti \& Furtado (2001, 2006 and 2009).

\section{ACKNOWLEDGMENTS}

Thanks are due to Luis Américo Conti, Marcelo Rodrigues, Roberto Lima Barcellos and Jarbas Bonetti Filho who have been working with me on studies about sedimentation and sea level fluctuations on the continental shelf of São Paulo and contributed greatly to this work.

\section{REFERENCES}

CORRÊAICS. 1979. Paleolinhas de costa na plataforma continental entre São Paulo e Santa Catarina. In: Simpósio Regional de Geologia, 2 ed. Atas. Rio Claro, SBG, 1: 269-278.

CORRÊA ICS. 1990. Analyse morphostructurale et evolution paleogeographique de la plateforme continentale atlantique sud-bresilienne (Rio Grande do Sul - Brasil). Universite de Bordeaux I. Doctorate. 314 pp.

CORRÊA ICS. 1996. Les variations du niveaux de la mer durant les derniers 17.500 ans BP: l'example de la plate-forme continentale du Rio Grande do Sul-Brasil. Marine Geology, 130: 163-178.

CORRÊA ICS, PONZI VRA \& TRINDADE LAF. 1980. Níveis marinhos quaternários da plataforma continental do Rio de Janeiro. In: Ed. Congresso Brasileiro de Geologia, 31. Proceedings. Camboriú, SBG, 1: 578-587.

CORRÊA ICS, BAITELLI R, SANTOS HM \& ADE MVB. 1989. Sea levels changes in south brazilian continental shelf. In: International Symposium on global changes in South America during the Quaternary: PastPresent-Future. Spec. Publ. no 1. São Paulo, Associação Brasileira de Estudos do Quaternário. 245-279.

CORRÊA ICS, MARTINS LRS, KETZER JMM, ELIAS ARD \& MARTINS R. 1996. Evolução sedimentológica e paleogeográfica da plataforma continental sul e sudeste do Brasil. Notas Técnicas, 9: 51-61.
COSTA MPA, ALVES EC, PACHECO PG \& MAIA AS. 1988. Prováveis estabilizações do nível do mar holocênico em trechos da plataforma continental entre o norte de São Paulo e o sul do Rio de Janeiro, constatadas através de morfologia de detalhe. In: Congresso Brasileiro de Geologia, 35, Proceedings..., Belém. Sociedade Brasileira de Geologia, v. 2: $436-450$.

MILLIMAN JD \& EMERY K0. 1968. Sea levels during the past 35,000 years. Science, 162: 1121-1123.

FURTADO VV, MAHIQUES MM, REINHARDT D, BONETTI FILHO J, FIGUEIREDO Jr AG de \& THEILENF. 1993. Evidences of sea level fluctuation in the northern continental shelf of São Paulo State, Brasil. JOPS-I WORKSHOP, Niterói, RJ, Alfred Wegener Institute for Polar and Marine Research, Bremerhaven, Germany, 20 pp.

FURTADO VV, MAHIQUES MM \& TESSLER MG. 1992. Utilização de Feições topográficas submersas na correlação de paleoníveis marinhos: uma avaliação. In: Congresso da Associação Brasileira de Estudos do Quaternário, 3 Proceedings... Associação Brasileira de Estudos do Quaternário. Belo Horizonte, 175-186.

FURTADO VV, BONETTI FILHO J \& CONTI LA. 1996. Paleo river valley morphology and sea level changes. Anais da Academia Brasileira de Ciências, 68 (supl. 1): 163-169.

FURTADO VV, RODRIGUES M \& BONETTI FILHO J. 1997. Estabilização do nível do mar na plataforma continental do estado de São Paulo no último máximo regressivo. In: VII Congresso Latino-Americano sobre Ciências do Mar, Associação Latino-Americana de Investigadores em Ciências do Mar/Instituto Oceanográfico-USP, Santos, SP. Extended abstracts, 338-339.

FURTADO VV, BONETTI FILHO J, RODRIGUES M \& BARCELLOS RL. 1998. Aspectos da sedimentação do Canal de São Sebastião. Technical report. Instituto. Oceanográfico, 43: 15-31. 
KOWSMANN RO \& COSTA MPA. 1974. Paleolinhas de costa na plataforma continental das regiões norte e sul brasileiras. Revista Brasileira de Geociências, 4(4): 215-222.

KOWSMANN RO \& COSTA MPA. 1978. Evidence of Late Quaternary sea level stillstands on the upper brazilian continental margin: a synthesis. In: 1978 International Symposium on Coastal Evolution in the Quaternary. Proceedings... Sociedade Brasileira de Geologia/Instituto de Geociências-USP, São Paulo, p. 172-192.

KOWSMANN RO \& COSTA MPA. 1979. Sedimentação quaternária da margem continental brasileira e das áreas oceânicas adjacentes (Final report). Série Projeto REMAC 8. Petrobras. Rio de Janeiro, 55 pp.

KOWSMANN RO, COSTA MPA, VICALVI MA, COUTINHO MGN \& GAMBOA LAP. 1977. Modelo de sedimentação holocênica na plataforma continental sul brasileira. In: Projeto REMAC. Evolução sedimentar holocênica da plataforma continental e do talude sul do Brasil. Série Projeto REMAC 2, Petrobras, Rio de Janeiro. 7-26.

MACINTYRE IG, PYLKEY OH \& STUCKENRATH R. 1978. Relict oyster on the United State Atlantic continental shelf: a reconsideration of their usefulness in understanding Late Quaternary sea level history. Geol. Soc. Am. Bull., 89: 277-282.

MARTINS LR, URIEN CM \& BUTLER LW. 1972. Províncias fisiográficas e sedimentos da margem continental atlântica da América do Sul. In:
Congresso Brasileiro de Geologia, 26, Proceedings, Belém, Sociedade Brasileira de Geologia, 2: 105-114.

MÖRNER NA. 1976. Eustasy and Geoid Changes. J. Geol. 84: 132-151.

REINHARDT D, BONETTI FILHO J, ALMEIDA TIR \& FURTADO VV. 1993. Análise de feições topográficas submersas por meio de um sistema de informações geográficas. In: Congresso da Associação Brasileira de Estudos do Quaternário, 4, Associação Brasileira de Estudos do Quaternário. São Paulo, SP, Resumos, p. 55-56.

SWIFT DJP. 1976. Continental Shelf Sedimentation. In: STANLEY DJ \& SWIFT DJP (Eds.). Marine Sediments Transport and Environmental Management. John Wiley \& Sons, Toronto, p. 311-377.

VICALVI MA, COSTA MPA \& KOWSMANN RO. 1978. Depressão de Abrolhos: uma paleolaguna holocênica na plataforma continental leste brasileira. Bol. Téc. Petrobras, 21(4): 279-286.

ZEMBRUSCKI SG. 1979. Geomorfologia da margem continental sul brasileira e das bacias oceânicas adjacentes. In: CHAVES HAF (Ed.). Geomorfologia da margem continental brasileira (Final report) Série Projeto REMAC, 7, Rio de Janeiro, p. 129-177.

ZEMBRUSCKI SG, BARRETO HT, PALMA JC \& MILLIMAN JD. 1972. Estudo preliminar das províncias geomorfológicas da margem continental brasileira. In: Congresso Brasileiro de Geologia, 26, Proceedings, Belém, Sociedade Brasileira de Geologia, 2: 187-210.

Recebido em 23 novembro, 2010 / Aceito em 27 abril, 2012

Received on November 23, 2010 / Accepted on April 27, 2012

\section{NOTE ABOUT THE AUTHOR}

Valdenir Veronese Furtado. Graduate in geology in the Instituto de Geociência e Astronomia of the Universidade de São Paulo. Doctorade in geosciences in the Universidade de São Paulo. Livre Docência at Institute of Oceanography. Specialization in coastal marine sedimentation. Worked at the Institute of Oceanography until 2010. 